\title{
EPOXY COMPOSITES FILLED WITH NATURAL CALCIUM CARBONATE. 3. EPOXY COMPOSITES OBTAINED IN THE PRESENCE OF MONOCARBOXYLIC DERIVATIVE OF EPIDIAN-6 EPOXY RESIN
}

\author{
Michael Bratychak $^{1, \otimes}$, Olena Astakhova ${ }^{1}$, Olena Shyshchak ${ }^{1}$
}

https://doi.org/10.23939/chcht14.04.504

\begin{abstract}
A monocarboxylic derivative of Epidian-6 with free epoxy and carboxylic end groups (MCDER) has been synthesized using Epidian-6 epoxy resin and sebacic acid. The structure of MCDER was confirmed by a spectral analysis. The thermal stability of MCDER has been established and the formation of cross-linked films based on epoxy-oligomeric mixtures consisting of Epidian-5, TGM-3 oligoesteracrylate, and polyethylene polyamine has been studied in its presence. By means of IR spectroscopy, the chemistry of the mixtures formation has been established. Physico-mechanical characteristics and morphology of the epoxy-oligomeric mixture based samples which were filled with $\mathrm{CaCO}_{3}$ have been determined.
\end{abstract}

Keywords: epoxy resin, sebacic acid, oligoesteracrylate, $\mathrm{CaCO}_{3}$, hardener, IR- and NMR-spectroscopy, crosslinking, physico-mechanical properties, SEM.

\section{Introduction}

The polymer based products are very important in present-day life $[1,2]$. Therefore the production of composites which are characterized by special operational properties is one of the most important tasks of polymer chemistry [3,4]. Nowadays epoxy resins (ER) are the mostly used components to produce composites $[5,6]$. The reason is their advantages over other polymers such as easiness during products formation and good operational characteristics of the final products [6]. For many years the researches regarding the creation of ER based oligomers with various functional groups [7-12] have been conducted at Lviv Polytechnic National University (Ukraine).

The synthesized oligomers allow to significantly improve the operational properties of the products based on them but increase the price of the final products. To decrease the price, it is possible to introduce fillers into

\footnotetext{
${ }^{1}$ Lviv Polytechnic National University

12, S.Bandery St., 79013 Lviv, Ukraine

mbratychak@gmail.com

(c) Bratychak M., Astakhova O., Shyshchak O., 2020
}

the epoxy-oligomeric mixtures [13]. Moreover, the filler may also improve the operational properties of the final products $[5,6]$. Among all known mineral fillers $\mathrm{CaCO}_{3}$ is most often used [14-18].

The possibility of using oligomers with different functional groups, as well as $\mathrm{CaCO}_{3}$ to obtain products based on Epidian-5 has been described in [16, 19]. Monoperoxy derivative [16] and monomethacrylic derivative [19] of Epidian-6 were used as oligomers. Monoperoxy derivative of Epidian-6 contains free epoxy and peroxy groups and monomethacrylic derivative of Epidian- 6 contains free epoxy group and methacrylic fragment. The presence of the mentioned oligomers in the mixtures based on Epidian-5 industrial resin and TGM-3 oligoesteracrylate provides a chemical interaction between the mixture components and thus leads to the improvement of the operational properties of the final products.

The aim of this work was to study epoxyoligomeric mixtures which are filled with $\mathrm{CaCO}_{3}$ and contain monocarboxylic derivative of Epidian-6. MCDER contains free epoxy and carboxy groups. Its formula is given below:

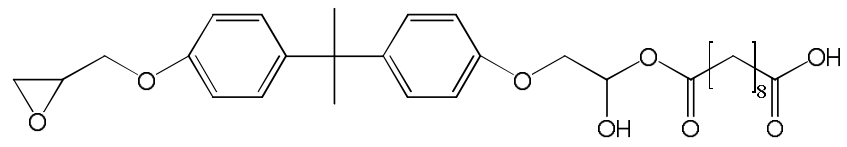

MCDER

\section{Experimental}

\subsection{Materials}

The materials used for the experiments were: Epidian-5 and Epidian-6 epoxy resins (Sarzyna-Ciech, Poland) with a molecular weight $\left(M_{n}\right)$ of 390 and $340 \mathrm{~g} / \mathrm{mol}$, respectively, and epoxy groups content (e.n.) of 20.0 and $24 \%$, respectively. Sebacic acid (SA, Aldrich) was used as received without additional purification. TGM-3 oligoesteracrylate (Ukraine) is an esterification product of methacrylic acid and triethylene glycol with $M_{n}$ $286 \mathrm{~g} / \mathrm{mol}$. Polyethylene polyamine (PEPA, Ukraine) is 
the curing agent and was used as received without additional purification. Benzyltriethylammonium chloride (BTEAC, Aldrich) was used as a catalyst for the reaction of Epidian-6 and SA. Calcium carbonate $\left(\mathrm{CaCO}_{3}\right.$, Sigma Aldrich) is a white odorless powder or colorless crystals.

\subsection{Methods of Analysis}

Molecular weight was determined by a cryoscopy [20] using dioxane as a solvent.

The content of epoxy or carboxy groups (\%) was determined according to the procedure described in [21].

The concentration of carboxy groups $\left(\left[C_{\text {carb.gr. }}\right]\right.$, mol/l) was calculated according to Eq. (1):

$$
\left[C_{\text {carb.gr. }}\right]=\frac{V_{w} \cdot N \cdot K}{V_{s}}
$$

where $V_{w}$ is an amount of $\mathrm{KOH}$ solution spent for the titration of the acid groups containing in the sample, $\mathrm{ml}$; $V_{s}$ is a sample volume, $\mathrm{ml}, V_{s}=0.5 \mathrm{ml} ; N$ is the $\mathrm{KOH}$ solution normality, $N=0.1 ; K$ is a correction factor for $0.1 \mathrm{~N} \mathrm{KOH}$.

IR spectroscopic investigations were conducted using a Specord- 80 within a range of $4000-400 \mathrm{~cm}^{-1}$. The samples were prepared as the films formed from the oligomer solution in chloroform or dioxane and applied on a $\mathrm{KBr}$ plate; the films thickness was $0.03 \mathrm{~mm}$.

IR spectroscopic investigations of epoxy-oligomeric mixtures during cross-linking were conducted using a spectrophotometer Thermal Electron CorporationNicolet 8700 with Specac Golden Gate adapter and diamond ATR crystal. The samples were prepared as the films applied on a $\mathrm{KBr}$ plate. The film was pressed by another plate using a mechanical device. The plates were placed in a desiccator at room temperature for $24 \mathrm{~h}$. The spectra were recorded at $423 \mathrm{~K}$ every $30 \mathrm{~min}$.

${ }^{1} \mathrm{H}$ and ${ }^{13} \mathrm{C}$ NMR investigations were carried out at 400 and $100 \mathrm{~Hz}$, respectively, in deuterochloroform at room temperature, using a spectrometer Bruker Advance II 400 (Poland).

Thermographic investigations were carried out using Thermogravimetric Analyzer TGA-7 in the atmosphere of nitrogen or air with $\mathrm{O}_{2}$ content of $8 \%$. The samples were heated to $973-1173 \mathrm{~K}$, the heating rate was $223 \mathrm{~K} / \mathrm{min}$, for some samples $-263 \mathrm{~K} / \mathrm{min}$. The heating time was $30-45 \mathrm{~min}$.

\subsection{The Reaction of Epidian-6 and SA}

The reaction was studied in a three-necked reactor equipped with a mechanical stirrer, thermometer, and backflow condenser. Epidian-6 and SA dissolved in isopropanol were loaded into the reactor. The mixture was heated, stirred and BTEAC was added. The reaction was controlled by the change in carboxy groups concentration (Eq. (1)).
The results obtained were used to plot the dependencies and to calculate the effective rate constants. The interpretation of the results in the $\lg K_{e f}-1 / T$ coordinates permits to calculate the activation energy of the reaction.

\subsection{MCDER Synthesis}

MCDER was synthesized in a three-necked reactor equipped with a mechanical stirrer, thermometer, backflow condenser and drop funnel. $90 \mathrm{~g}$ of Epidian-6, $300 \mathrm{ml}$ of toluene and $17.1 \mathrm{~g}$ of BTEAC dissolved in $20 \mathrm{ml}$ of water were loaded into the reactor. The mixture was heated to $343 \mathrm{~K}$ under stirring and $51.0 \mathrm{~g}$ of SA dissolved in $300 \mathrm{ml}$ of isopropyl alcohol were added dropwise for $2.5 \mathrm{~h}$. The mixture was stirred additionally for $1 \mathrm{~h}$ and cooled to room temperature. After adding $100 \mathrm{ml}$ of benzene it was placed in a separation funnel. The catalyst was washed out by water and the organic layer was vacuumized at $323 \mathrm{~K}$ till the constant weight. The resulting oligomer yield was $88.5 \mathrm{~g}(94 \%), M_{n}$ $550 \mathrm{~g} / \mathrm{mol}$, content of carboxy groups $8 \%$, and content of epoxy groups $7.8 \%$. MCDER is a light-yellow viscous substance dissolved in isopropyl alcohol, dioxane, acetone and other organic solvents.

\subsection{Preparation of Unfilled Epoxy- Oligomeric Mixtures}

Epoxy-oligomeric films were prepared by applying the mixture over glass standard plates. The mixture was prepared by mixing Epidian-5, MCDER, TGM-3 and PEPA. The cross-linking was carried out stepwise: first at room temperature for $24 \mathrm{~h}$, then at 383 or 403 or $423 \mathrm{~K}$ for $15,30,45,60$ or $75 \mathrm{~min}$.

\subsection{Preparation of Filled Epoxy Oligomeric Mixtures}

Epidian-5, TGM-3, MCDER and $\mathrm{CaCO}_{3}$ were mixed till the homogeneous mixture was obtained. Then it was vacuumized to eliminate air bubbles. After PEPA addition the mixture was again mixed and vacuumized.

To determine the film hardness and gel-fraction content the samples were applied over the standard glass plates. To determine physico-mechanical properties the samples were poured into special moulds in the form of shovels and bars [16]. The shovels and bars were formed at room temperature for 10 days.

\subsection{Investigation Methods}

The films hardness, gel-fraction content, physicomechanical properties and SEM analysis of the filled mixtures were determined according to the procedure described in [16]. 


\section{Results and Discussion}

\subsection{MCDER Obtaining, Characteristics and Properties}

\subsubsection{MCDER obtaining}

The synthesis of oligomers with free epoxy and carboxy groups in their structure is of great interest from the standpoint of practical application. It means that it would be possible to extend the compatibility of these compounds with other polymeric materials, as well as to improve the properties of the products on their basis. Bashta et al. [10] described the oligomeric product obtained on the basis of dianic epoxy resin Epidian- 6 and adipic acid.

We propose to synthesize oligomer on the basis of Epidian-6 and sebacic acid according to Eq. (2):<smiles>CC(C)(c1ccc(OCC2CC2)cc1)c1ccc(OCC2CC2C(C)(CC(=O)O)CC(=O)O)cc1</smiles>

Epidian-6

SA<smiles>CC(CC(C)C(=O)O)OC(O)COc1ccc(C(C)(C)c2ccc(OCC3OC3C)cc2)cc1</smiles>

Sebacic acid has a longer aliphatic chain compared with adipic acid and this fact would influence the resulting product properties. Benzyltriethylammonium chloride (BTEAC) is a catalyst. The mixture of toluene and isopropyl alcohol is a solvent.

The effect of temperature on the reaction proceeding is depicted in Fig. 1. The effective rate constants of the reaction (see Eq. (2)) are represented in Table 1. Interpretation of the results in the Arrhenius coordinates allows to calculate the activation energy of the reaction (Fig. 2) which was found to be $39.0 \pm 1.0 \mathrm{~kJ} / \mathrm{mol}$.

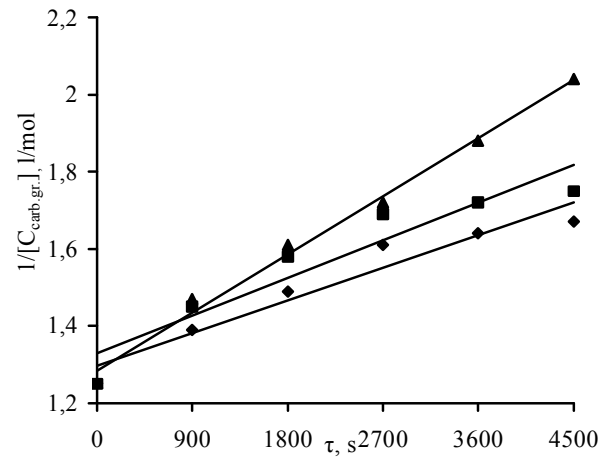

Fig. 1. Kinetic anamorphoses for the reaction of Epidian-6 and SA at different temperatures (K): 333 (1), 343 (2) and 353 (3). BTEAC amount is $30 \mathrm{~mol} \%$ per $1 \mathrm{~g}$-eq. of SA carboxy group.

SA content is 1 mole per $1 \mathrm{~g}$-eq. of Epidian-6 epoxy group

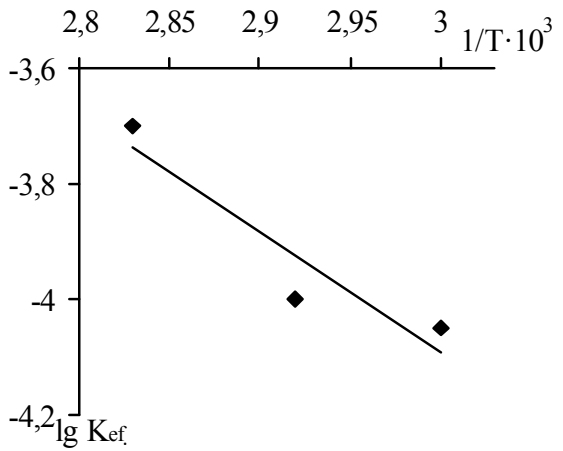

Fig. 2. Dependence of $\lg K_{e f}$ on $1 / T$ for the reaction of Epidian- 6 and SA in the presence of BTEAC $=30 \mathrm{~mol} \%$ per 1 g-eq. of SA carboxy group. SA content $=1$ mole per 1 g-eq. of Epidian-6 epoxy group

\section{Effective reaction rates of Epidian-6 and SA reaction}

\begin{tabular}{|c|c|c|}
\hline Temperature, $\mathrm{K}$ & $K_{e f} 10^{4}, \mathrm{l} / \mathrm{mol} \cdot \mathrm{s}$ & ${\text { Correlation coefficient } R^{2}}^{2}$ \\
\hline 333 & $1.17 \pm 0.13$ & 0.9342 \\
\hline 343 & $1.56 \pm 0.13$ & 0.8977 \\
\hline 353 & $1.74 \pm 0.13$ & 0.9918 \\
\hline
\end{tabular}

Note: BTEAC amount is $30 \mathrm{~mol} \%$ per $1 \mathrm{~g}$-eq. of SA carboxy group 


\subsubsection{IR spectroscopic investigations}

To confirm the MCDER structure we recorded the IR-spectrum (Fig. 3). The interpretation of the spectrum is given in Table 2. The data for Epidian-6 are given for the comparison.

One can see that MCDER contains epoxy groups, the same as Epidian-6. The absorption bands at $912 \mathrm{~cm}^{-1}$ and fragments of benzene rings at 1608 and $1512 \mathrm{~cm}^{-1}$ confirm this fact. However, unlike Epidian-6, the MCDER molecule contains absorption bands at 1258, 1045 and $1730 \mathrm{~cm}^{-1}$ indicating the presence of sebacic acid in its structure. The appearance of the absorption band at $3457 \mathrm{~cm}^{-1}$ indicates the bonding of SA molecule to Epidian $=6$ due to the opening of the epoxy ring (see Eq. (2)).

\subsection{3. ${ }^{1} \mathrm{H}$ NMR spectroscopic investigations}

These investigations were carried out to confirm the MCDER structure. The spectrum of the initial Epidian-6 was recorded for the comparison. The interpretation of the spectra is given in Table 3 .
The epoxy groups in MCDER are confirmed by the proton signals at $2.71-3.32 \mathrm{ppm}$. The hydroxy groups which are absent in the initial Epidian-6, are confirmed by the signal at $4.00 \mathrm{ppm}$. Both Epidian-6 and MCDER contain benzene fragments, $-\mathrm{CH}_{2}-,-\mathrm{CH}_{2} \mathrm{O}-,-\mathrm{CHO}-$ and $\mathrm{H}_{3} \mathrm{C}-\stackrel{\mathrm{C}-}{\mid}-\mathrm{CH}_{3}$ fragments.

\subsection{4. ${ }^{13} \mathrm{C}$ NMR spectroscopic investigations}

The hydroxy groups in the structure of the synthesized MCDER (cf. initial Epidian-6) were determined by ${ }^{1} \mathrm{H}$ NMR spectroscopy. This fact confirms the bonding of SA molecules to Epidian- 6 due to the opening of the epoxy ring according to Eq. (2). ${ }^{13} \mathrm{C}$ NMR spectroscopy was used to confirm the presence of SA fragments in the MCDER structure. The initial Epidian-6 was studied for the comparison. The obtained results are given in Table 4.

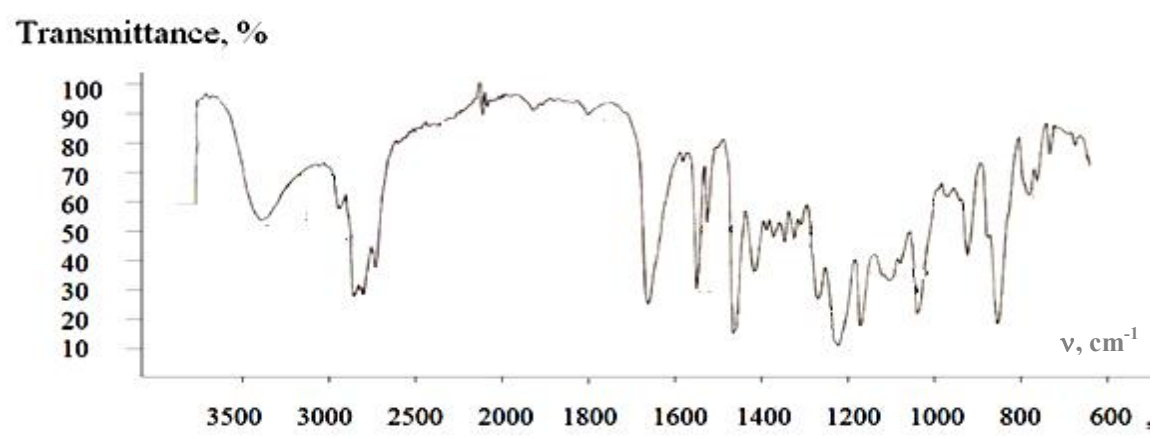

Fig. 3. IR spectrum of MCDER

IR spectroscopic characteristics of oligomers

\begin{tabular}{|c|c|c|c|c|c|c|}
\hline \multirow{3}{*}{ Oligomer } & \multicolumn{6}{|c|}{ IR absorption bands, $\mathrm{cm}^{-1}$} \\
\hline & \multirow{2}{*}{$\frac{-\mathrm{OH}}{v_{\mathrm{OH}}}$} & \multirow{2}{*}{$\frac{V_{0}}{v_{\text {sym }}}$} & \multicolumn{3}{|c|}{$\stackrel{\mathrm{O}}{\|}-\stackrel{\mathrm{C}}{\mathrm{C}}-\mathrm{O}$} & \\
\hline & & & $v_{(\mathrm{C}-\mathrm{O}-\mathrm{O}) \mathrm{as}}$ & $v_{(\mathrm{C}-\square \mathrm{O}-\mathrm{C}) \mathrm{sym}}$ & $v_{\mathrm{C}=\mathrm{O}}$ & $v 0$ \\
\hline Epidian-6 & - & 912 & - & - & - & 1605,1513 \\
\hline MCDER & 3457 & 912 & 1258 & 1045 & 1730 & 1608,1512 \\
\hline
\end{tabular}

Table 3

${ }^{1}$ H NMR spectroscopic characteristics of oligomers

\begin{tabular}{|c|c|c|c|c|c|c|c|}
\hline \multirow{3}{*}{ Oligomer } & \multicolumn{7}{|c|}{ Chemical shift, ppm } \\
\hline & & & & $-\mathrm{CH}_{2} \mathrm{O}-$ & & & \\
\hline & & & $\mathrm{C}_{6} \mathrm{H}_{4} \mathrm{X}_{2}$ & & 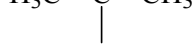 & & $\mathrm{Cr}_{2}$ \\
\hline Epidian-6 & 2.72 & 3.34 & $6.80-7.15$ & $3.90-4.00$ & 1.62 & - & 1.15 \\
\hline MCDER & 2.71 & 3.32 & $6.80-7.10$ & $3.80-4.32$ & 1.62 & 4.00 & 1.19 \\
\hline
\end{tabular}


${ }^{13}$ C NMR spectroscopic characteristics of oligomers

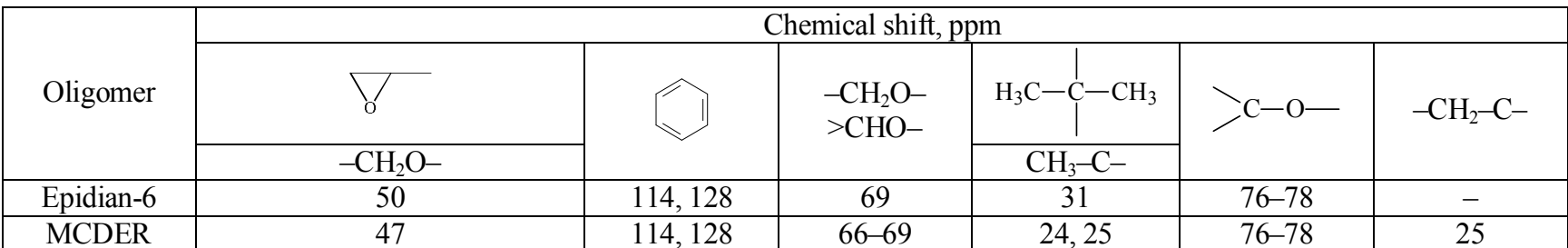

In the synthesized MCDER we observed the signals at $25 \mathrm{ppm}$ corresponding to the aliphatic fragments $-\mathrm{CH}_{2}-\mathrm{C}-$. Such fragments are absent in the initial Epidian-6 indicating that SA fragments were introduced into the MCDER structure.

\subsubsection{Thermal stability of MCDER}

To estimate the possibility of MCDER usage in various polymer compositions we studied its thermal stability. The results are represented in Fig. 4 and Table 5.

One can see that the synthesized MCDER has a sufficient thermal stability. The destruction is observed at $473 \mathrm{~K}$ (Fig. 4). The sharp mass loss occurs in the region of $663-773 \mathrm{~K}$ and achieves $78 \%$ at $773 \mathrm{~K}$ (Table 5). The decrease in mass by $88 \%$ takes place at $946 \mathrm{~K}$. Thus, MCDER is thermostable to the temperature of $623 \mathrm{~K}$ and may be used in those mixtures which have high thermal stability.

\subsection{Cross-linking of Unfilled Epoxy- Oligomeric Mixtures}

MCDER with free epoxy and carboxy groups in its structure may be used as an active additive to polymeric mixtures based on the industrial epoxy resins. For such mixtures, the oligoesteracrylate TGM-3 is used as a plas- ticizer. It is known [22] that TGM-3 does not react with the mixture components and does not participate in the cross-linking. The products based on the mentioned polymeric mixtures have short service life because of deterioration in the operational performance.

The cross-linking properties of MCDER were studied according to the procedure described in subsection 2.5. Epidian-5 was used as an initial epoxy resin, TGM-3 - as a plasticizer and polyethylene polyamine (PEPA) - as a hardener.

The composition of epoxy-oligomeric mixtures based on Epidian-5 and MCDER is represented in Table 6. The mixture without MCDER (mixture IV) and the mixture without TGM-3 (mixture V) were studied for the comparison. The cross-linking was carried out according to the procedure described in subsection 2.5 and the results obtained are represented in Table 7.

So, the gel-fraction content and films hardness depend on the mixture composition, cross-linking temperature and time. The increase in MCDER amount from 9 to 36 mass parts decreases the gel-fraction content and hardness at room temperature. It means that under such conditions the cross-linking occurs in the presence of Epidian-5 only, due to the interaction of its epoxy groups and PEPA. MCDER with one epoxy group is only grafted to the matrix based on Epidian-5. TGM-3 molecules do not participate in the process.

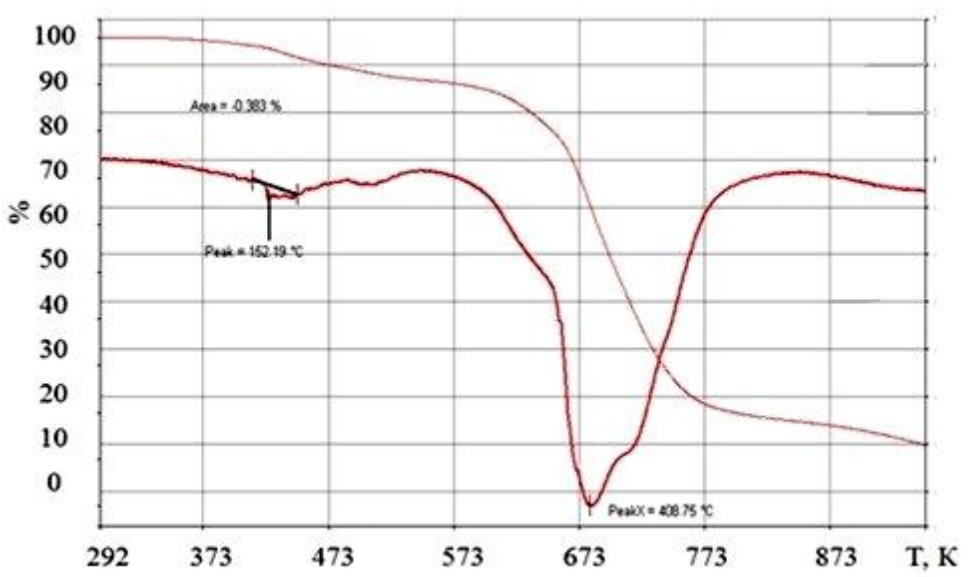

Fig. 4. Derivatographic curves for MCDER 
Thermal stability of MCDER

Table 5

Temperature at which mass loss is observed, K/mass loss, $\%$

\begin{tabular}{|c|c|c|c|}
\hline \multicolumn{3}{|c|}{ Temperature at which mass loss is observed, K/mass loss, \% } \\
\hline \multicolumn{2}{|c|}{ First stage of mass loss } & Second stage of mass loss \\
\hline beginning & end & $773 / 78$ & end \\
\hline 433 & 773 . & $946 / 88$
\end{tabular}

Table 6

The composition of epoxy-oligomeric mixtures

\begin{tabular}{|c|c|c|c|c|c|}
\hline \multirow{2}{*}{ Component } & \multicolumn{5}{|c|}{ Components content, mass parts } \\
\hline & $\mathrm{I}$ & II & III & IV & $\mathrm{V}$ \\
\hline Epidian-5 & 82 & 73 & 55 & 91 & 60 \\
\hline MCDER & 9 & 18 & 36 & - & 40 \\
\hline TGM-3 & 9 & 9 & 9 & 9 & - \\
\hline PEPA & 13 & 9 & 9 & 14 & 9 \\
\hline
\end{tabular}

Note: PEPA amount was calculated per amount of epoxy groups in Epidian-5 and MCDER based on the ratio 14 mass parts of PEPA per $20 \mathrm{~g}$ of epoxy groups

Table 7

Dependence of gel-fraction content and polymer film hardness on cross-linking temperature and time

\begin{tabular}{|c|c|c|c|c|c|c|c|c|}
\hline \multirow[b]{2}{*}{$\begin{array}{c}\text { Temperature, } \\
\mathrm{K}\end{array}$} & \multirow{2}{*}{$\begin{array}{c}\text { Mixture } \\
\text { number } \\
\text { according } \\
\text { to Table } 6\end{array}$} & \multirow[b]{2}{*}{ Index } & \multicolumn{6}{|c|}{ Index value for cross-linking time, $\min$} \\
\hline & & & $\begin{array}{c}24 \mathrm{~h}, \\
\text { normal } \\
\text { conditions }\end{array}$ & 15 & 30 & 45 & 60 & 75 \\
\hline \multirow{6}{*}{383} & \multirow{2}{*}{ I } & $G$ & 81.3 & 86.2 & 88.7 & 89.1 & 89.4 & 90.1 \\
\hline & & $H$ & 0.54 & 0.73 & 0.81 & 0.83 & 0.85 & 0.85 \\
\hline & \multirow{2}{*}{ II } & $G$ & 77.6 & 80.1 & 82.2 & 83.5 & 85.2 & 86.2 \\
\hline & & $H$ & 0.43 & 0.64 & 0.70 & 0.77 & 0.80 & 0.83 \\
\hline & \multirow{2}{*}{ III } & $G$ & 44.5 & 51.3 & 76.3 & 78.9 & 80.4 & 82.4 \\
\hline & & $H$ & 0.17 & 0.22 & 0.64 & 0.74 & 0.77 & 0.88 \\
\hline \multirow{6}{*}{403} & \multirow{2}{*}{ I } & $G$ & 81.3 & 89.1 & 88.8 & 89.2 & 90.0 & 90.4 \\
\hline & & $H$ & 0.54 & 0.81 & 0.82 & 0.87 & 0.89 & 0.91 \\
\hline & \multirow{2}{*}{ II } & $G$ & 77.6 & 82.0 & 83.9 & 84.8 & 86.0 & 87.6 \\
\hline & & $H$ & 0.43 & 0.76 & 0.89 & 0.92 & 0.94 & 0.95 \\
\hline & \multirow{2}{*}{ III } & $G$ & 44.5 & 53.4 & 77.2 & 84.9 & 86.9 & 86.9 \\
\hline & & $H$ & 0.17 & 0.29 & 0.75 & 0.94 & 0.97 & 0.98 \\
\hline \multirow{10}{*}{423} & \multirow{2}{*}{ I } & $G$ & 81.3 & 89.8 & 91.0 & 91.5 & 91.7 & 92.3 \\
\hline & & $H$ & 0.54 & 0.87 & 0.88 & 0.93 & 0.95 & 0.95 \\
\hline & \multirow{2}{*}{ II } & $G$ & 77.6 & 83.7 & 84.1 & 85.2 & 85.7 & 88.1 \\
\hline & & $H$ & 0.43 & 0.90 & 0.91 & 0.93 & 0.94 & 0.95 \\
\hline & \multirow{2}{*}{ III } & $G$ & 44.5 & 82.9 & 90.8 & 93.0 & 93.9 & 94.0 \\
\hline & & $H$ & 0.17 & 0.93 & 0.96 & 0.98 & 0.98 & 0.98 \\
\hline & \multirow{2}{*}{ IV } & $G$ & 72.6 & 79.2 & 86.5 & 87.6 & 92.2 & 92.2 \\
\hline & & $H$ & 0.27 & 0.70 & 0.82 & 0.87 & 0.87 & 0.88 \\
\hline & \multirow{2}{*}{$\mathrm{V}$} & $G$ & 80.5 & 91.4 & 92.6 & 92.9 & 93.9 & 94.0 \\
\hline & & $H$ & 0.44 & 0.81 & 0.83 & 0.87 & 0.88 & 0.91 \\
\hline
\end{tabular}

Notes: $G$ is a gel-fraction content, $\% ; H$ is a hardness determined by M-3 device, rel.units 
The mixture heating to 383,403 or $423 \mathrm{~K}$ increases both values of $G$ and $H$ (Table 7). The reason is the additional formation of cross-linked structures due to the reactions of Epidian-5 and MCDER epoxy groups and secondary amino groups of PEPA.

The cross-linking time also influences the gelfraction content and hardness. The increase in time increases both values. It means that during cross-linking other reactions occur apart from the reactions of epoxy groups and secondary amino groups. Other reactions include oligomerization of TGM-3 molecules and reaction of MCDER carboxy group with hydroxy groups of Epidian-5, as well as with hydroxy groups which are formed due to the reaction of Epidian-5 epoxy groups and PEPA at room temperature.

The possibility of the reaction between epoxy and carboxy groups was described by Ellis [6]. Moreover, the higher the temperature, the higher the reaction rate. The results obtained here confirm this fact (Table 7).

The higher the MCDER content (mixture III, Table 6 ) and the higher the temperature $(423 \mathrm{~K})$, the more crosslinked products are formed due to the reaction of MCDER carboxy groups with hydroxy groups, and threedimensional oligomerization of TGM-3 as well. At room temperature the mixture III (MCDER content is 36 mass parts) forms a film with $44.5 \%$ of cross-linked products and hardness of 0.17 rel.units. The heating of this mixture to $433 \mathrm{~K}$ for $30 \mathrm{~min}$ increases the gel-fraction content to $90.8 \%$ and hardness to 0.96 rel.units (Table 7).

The results obtained for mixture IV (without MCDER) confirm the proceeding of the reaction of epoxy groups with secondary amino groups, as well as a threedimensional oligomerization of TGM-3 at heating. The results for mixture $\mathrm{V}$ (without TGM-3) confirm the

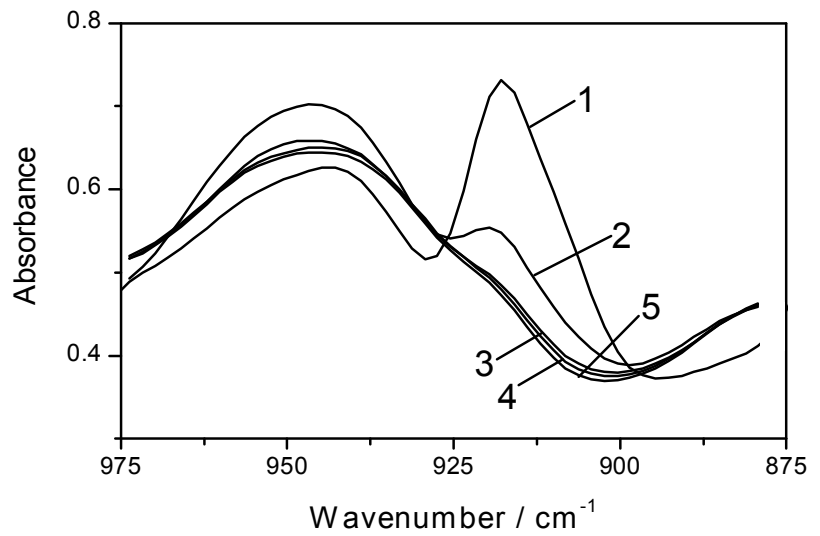

Fig. 5. Intensity of absorption band at $918 \mathrm{~cm}^{-1}$ after mixture preparation (1), after keeping at room temperature for $24 \mathrm{~h}(2)$, after heating at $423 \mathrm{~K}$ for $30 \mathrm{~min}(3), 60 \mathrm{~min}$ (4) and $90 \min (5)$ possibility of the reaction proceeding with the participation of MCDER carboxy groups.

\subsubsection{IR spectroscopic investigations}

To determine the chemistry of the cross-linking process in the presence of MCDER we carried out IR investigations for mixture III (Table 6). The structural changes were controlled by absorption bands at $918 \mathrm{~cm}^{-1}$ (typical of stretching vibrations of epoxy ring), at $3440 \mathrm{~cm}^{-1}$ (hydroxy group), $1717 \mathrm{~cm}^{-1}$ (carbonyl group in acids) and at $1731 \mathrm{~cm}^{-1}$ (carbonyl group in esters). It was found that spectra recorded after cross-linking at room temperature for $24 \mathrm{~h}$ differ from those recorded after heating to $423 \mathrm{~K}$ for 30, 60 and $90 \mathrm{~min}$ (Fig. 5).

The intensive absorption band at $918 \mathrm{~cm}^{-1}$ corresponding to the stretching vibrations of epoxy ring in Epidian-5 and MCDER is observed for the initial mixture III. After keeping the mixture at room temperature for $24 \mathrm{~h}$ the band intensity is decreased but it does not disappear. It means that epoxy groups of Epidian-5 and MCDER react with PEPA molecules according to Eq. (3):

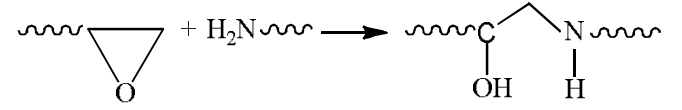

The intensity of the absorption band at $3440 \mathrm{~cm}^{-1}$ corresponding to the stretching vibrations of hydroxy group increases after keeping the mixture at room temperature for $24 \mathrm{~h}$. Further heating to $423 \mathrm{~K}$ leads to the complete depletion of epoxy groups (Fig. 5, curves 3-5). We observe the decrease in the intensity of absorption band at $3440 \mathrm{~cm}^{-1}$ indicating that at the temperature of $423 \mathrm{~K}$ the hydroxy groups react according to Eq. (4):
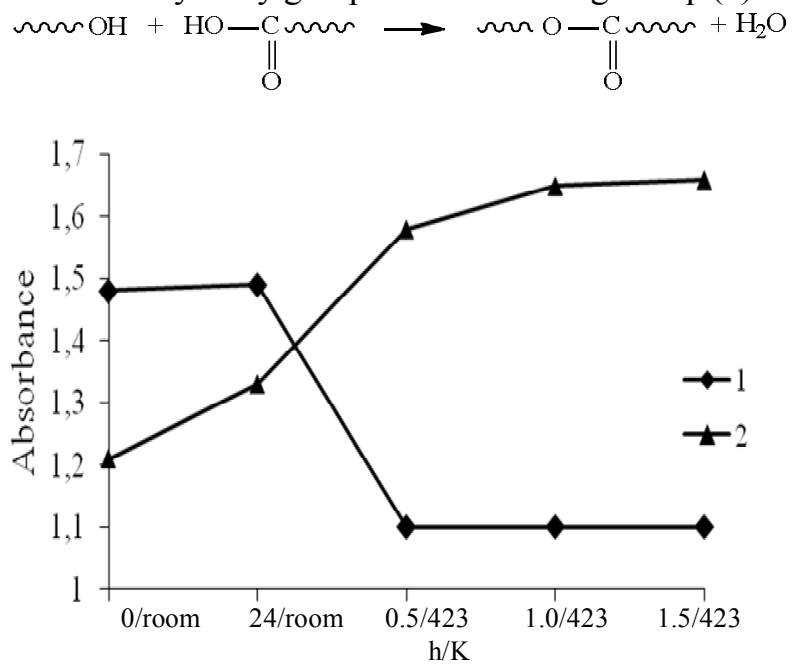

Fig. 6. Changes in the intensity of absorption bands at $1717 \mathrm{~cm}^{-1}$ typical of carbonyl group in acids (1) and at $1731 \mathrm{~cm}^{-1}$ typical of carbonyl group in esters (2) during crosslinking 
This leads to additional cross-linking of the mixture components due to the reaction of MCDER carboxy groups and hydroxy groups of the cross-linked structure formed according to Eq. (2). The increase in gel-fraction content (Eq. (4)) is confirmed by the results from Table 7. The proceeding of the reaction according to Eq. (4) is also confirmed by IR-spectroscopy (Fig. 6). The results represented in Fig. 6 show that at cross-linking of the mixture at room temperature the intensity of the band at $1717 \mathrm{~cm}^{-1}$, typical of carbonyl group in acids (curve 1), is not changed. This indicates that the reaction according to Eq. (3) does not proceed. The heating to $423 \mathrm{~K}$ for 30 $90 \mathrm{~min}$ results in the sharp decrease of the intensity. On the contrary, the intensity of absorption band at $1731 \mathrm{~cm}^{-1}$ (curve 2) increases at cross-linking of the mixture at room temperature and when heating, confirming in such a way the partial polymerization of TGM-3 molecules in both cases.

Thus, the IR-spectroscopic investigations confirm the participation of MCDER molecules in the formation of cross-linked structures based on epoxy-oligomeric mixtures.

\subsection{Cross-linking of Filled Epoxy- Oligomeric Mixtures}

As it was mentioned above, already at room temperature the synthesized MCDER participates in the formation of films based on epoxy-oligomeric mixtures (Table 7). On the other hand, to reduce the cost of such products and to improve their operational characteristics it was necessary to study the mixtures with a filler. Earlier we have shown $[16,19]$ that $\mathrm{CaCO}_{3}$ may be successfully used. So, here we investigated the epoxy-oligomeric mixtures filled with $\mathrm{CaCO}_{3}$ (Table 8). The obtained values of gelfraction content and hardness are represented in Table 9.

If we compare mixtures without $\mathrm{CaCO}_{3}$ (mixtures 1 and 2, Table 8), we see that the introduction of 10 mass parts of MCDER (mixture 2) does not affect gel-fraction content and hardness. The introduction of 10 mass parts of $\mathrm{CaCO}_{3}$ (mixture 3) increases both values. Further increase in the amount of $\mathrm{CaCO}_{3}$ to 30 mass parts (mixture 4) and 60 mass parts (mixture 5) decreases the film hardness and actually does not change the high content of gel-fraction.

Table 8

Composition of the filled epoxy-oligomeric mixtures

\begin{tabular}{|c|c|c|c|c|c|c|}
\hline \multirow{2}{*}{ Component } & \multicolumn{7}{|c|}{ Components content, mass parts } & $\mathbf{4}$ & $\mathbf{5}$ & $\mathbf{6}$ \\
\cline { 2 - 7 } & $\mathbf{1}$ & $\mathbf{2}$ & $\mathbf{3}$ & 90 & 90 & 100 \\
\hline Epidian-5 & 100 & 90 & 90 & 10 & 10 & 0 \\
\hline MCDER & 0 & 10 & 10 & 10 & 10 & 10 \\
\hline TGM-3 & 10 & 10 & 10 & 13.3 & 13.3 & 14.0 \\
\hline PEPA & 14.0 & 13.3 & 13.3 & 30 & 60 & 30 \\
\hline $\mathrm{CaCO}_{3}$ & 0 & 0 & 10 & 0 & \\
\hline
\end{tabular}

Note: PEPA amount was calculated per amount of epoxy groups in Epidian-5 and MCDER based on the ratio 14 mass parts of PEPA per $20 \mathrm{~g}$ of epoxy groups

Table 9

Dependence of gel-fraction content and film hardness on mixtures composition and cross-linking time

\begin{tabular}{|c|c|c|c|c|c|c|c|}
\hline \multirow{2}{*}{$\begin{array}{c}\text { Mixture } \\
\text { number } \\
\text { according to } \\
\text { Table } 8\end{array}$} & \multirow[b]{2}{*}{ Index } & \multicolumn{6}{|c|}{ Index value for cross-linking time, days } \\
\hline & & 1 & 2 & 4 & 7 & 9 & 10 \\
\hline \multirow{2}{*}{1} & $G$ & 82.2 & 83.1 & 85.6 & 87.3 & 89.5 & 91.7 \\
\hline & $H$ & 0.40 & 0.44 & 0.62 & 0.73 & 0.77 & 0.84 \\
\hline \multirow{2}{*}{2} & $G$ & 81.0 & 82.4 & 84.9 & 86.2 & 86.7 & $\overline{90.6}$ \\
\hline & $H$ & 0.32 & 0.49 & 0.64 & 0.68 & 0.79 & 0.82 \\
\hline \multirow{2}{*}{3} & $G$ & 80.1 & 84.6 & 88.3 & 89.4 & 92.4 & 93.0 \\
\hline & $H$ & 0.41 & 0.51 & 0.62 & 0.69 & 0.83 & 0.90 \\
\hline \multirow{2}{*}{4} & $G$ & 80.7 & 85.6 & 86.3 & 87.2 & 89.5 & 91.5 \\
\hline & $H$ & 0.27 & 0.39 & 0.50 & 0.54 & 0.60 & 0.63 \\
\hline \multirow{2}{*}{5} & $G$ & 81.6 & 85.9 & 86.9 & 87.2 & 87.4 & 90.2 \\
\hline & $H$ & 0.23 & 0.37 & 0.43 & 0.50 & 0.55 & 0.58 \\
\hline \multirow{2}{*}{6} & $G$ & 80.8 & 84.9 & 85.0 & 85.2 & 86.7 & 88.1 \\
\hline & $H$ & 0.17 & 0.33 & 0.38 & 0.50 & 0.53 & 0.57 \\
\hline
\end{tabular}

Notes: $G$ is a gel-fraction content, $\% ; H$ is a hardness determined by M-3 device, rel.units 
If we compare mixtures with (mixture 4) and without (mixture 6) MCDER, we see the higher values of $G$ and $H$ for the mixture with MCDER. This confirms once again the participation of MCDER molecules in the formation of films based on epoxy-oligomeric mixtures. The best results were achieved for the mixture 3 (MCDER amount is 10 mass parts, $\mathrm{CaCO}_{3}$ amount is 10 mass parts): $G=93.0 \% ; H=0.90$ rel.units.

\subsubsection{Physico-mechanical properties}

Physico-mechanical properties of the mixtures were studied according to the procedure described in subsection 2.7. The experimental results are given in Table 6 .

The comparison of mixtures without $\mathrm{CaCO}_{3}$ (mixtures $\mathbf{1}$ and 2, Table 8) shows that the introduction of
MCDER in the amount of 10 mass parts decreases the values of maximum tensile strength $\left(T S_{b}\right)$, elongation at break $\left(E_{b}\right)$, maximum flexural strength $\left(F_{\max }\right)$ and Charpy impact strength but slightly increases Young's modulus $\left(E_{M o d}\right)$ and the value of Shore D hardness. This indicates the effect of MCDER molecules on the physicomechanical properties of the products. The introduction of $\mathrm{CaCO}_{3}$ in the amount of 10 mass parts (mixture 3) compared with the mixture without the filler (mixture 2) increases the values of $T S_{b}, E_{b}, F_{\max }$ and Shore $\mathrm{D}$ hardness but decreases $E_{\text {Mod }}$, impact strength and e-break. So, the introduction of $\mathrm{CaCO}_{3}$ in the mixture increases the hardness but makes the product more brittle. The amount of $\mathrm{CaCO}_{3}$ more than 10 mass parts provides the increase in hardness but slight decrease of elasticity.

Table 10

Physico-mechanical properties of the filled epoxy-oligomeric mixtures

\begin{tabular}{|c|c|c|c|c|c|c|c|}
\hline \multirow{2}{*}{$\begin{array}{l}\text { Mixture num- } \\
\text { ber according } \\
\text { to Table } 8\end{array}$} & \multicolumn{3}{|c|}{ Tensile tests } & \multirow{2}{*}{$\begin{array}{l}\text { Charpy impact } \\
\text { strength, } \mathrm{kJ} / \mathrm{m}^{2}\end{array}$} & \multicolumn{2}{|c|}{ Flexural properties } & \multirow{2}{*}{$\begin{array}{l}\text { Shore D } \\
\text { hardness }\end{array}$} \\
\hline & $T S_{b}, \mathrm{MPa}$ & $E_{b}, \%$ & $E_{\text {Mod }}, \mathrm{GPa}$ & & $F_{\max }, \mathrm{MPa}$ & e-break, \% & \\
\hline 1 & 57.3 & 3.46 & 1.46 & 3.42 & 71.43 & 2.99 & 75.2 \\
\hline 2 & 26.1 & 1.30 & 1.67 & 2.77 & 39.15 & 2.05 & 77.7 \\
\hline 3 & 34.2 & 2.21 & 1.29 & 1.94 & 42.70 & 1.65 & 84.6 \\
\hline 4 & 23.5 & 1.58 & 1.35 & 2.89 & 39.09 & 1.47 & 82.6 \\
\hline 5 & 19.9 & 1.12 & 1.58 & 2.65 & 35.07 & 1.13 & 81.1 \\
\hline 6 & 26.2 & 1.70 & 1.30 & 1.92 & 39.69 & 1.54 & 84.0 \\
\hline
\end{tabular}

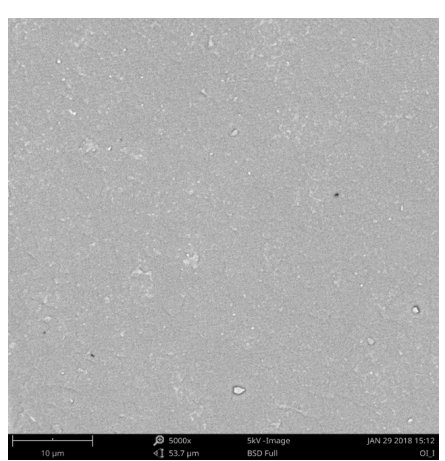

a)

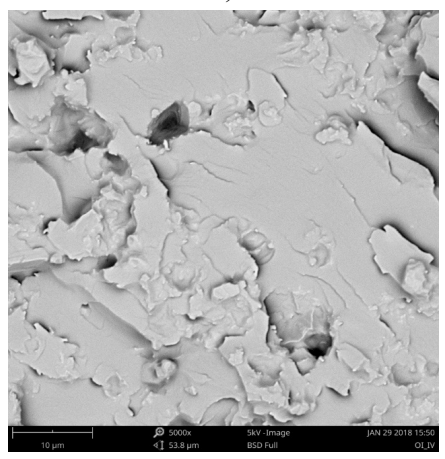

d)

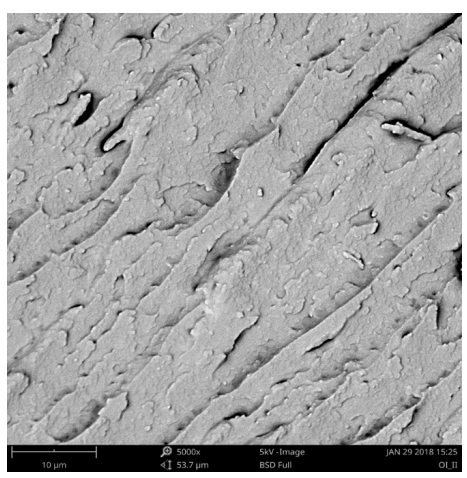

b)

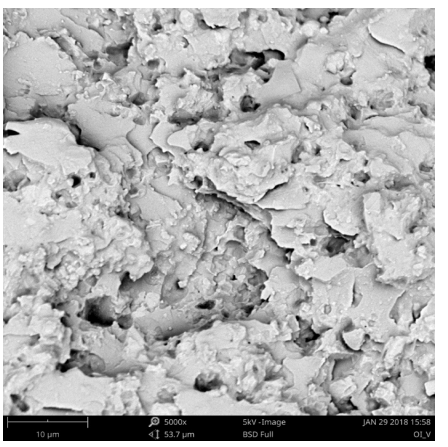

e)

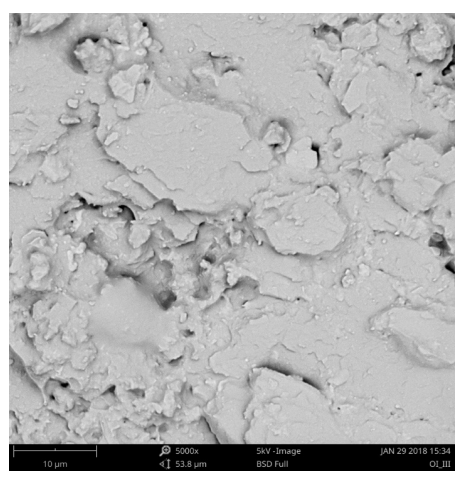

c)

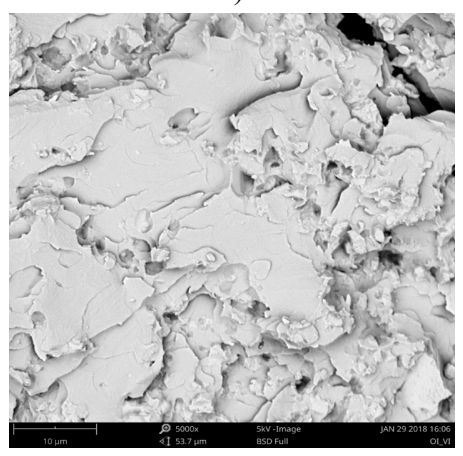

f)

Fig. 7. SEM images of mixtures 1 (a), 2 (b), 3 (c), 4 (d), 5 (e) and 6 (f) 
The comparison of the samples with equal amount of $\mathrm{CaCO}_{3}$ (mixtures $\mathbf{4}$ and $\mathbf{6}$, Table 8) shows higher values of $E_{M o d}$ and Charpy impact strength for the mixture $\mathbf{4}$ (mixture with 10 mass parts of MCDER). The values of $F_{\max }$, e-break and Shore D hardness are almost the same for both mixtures. This confirms once more the role of MCDER molecules in the formation of product structure.

The morphology of the samples under study is demonstrated in Fig. 7. The introduction of MCDER into the mixture ( $c f$. Figs. 7a and 7c) increases the product porosity resulting in the decrease of $T S_{b}, E_{b}$, and other characteristics (Table 10). At the same time the Shore D hardness is increased.

Simultaneous introduction of MCDER and $\mathrm{CaCO}_{3}$ (Fids. $7 \mathrm{c}-7 \mathrm{e})$ increases the porosity. Moreover, from the SEM images of mixtures 2, 4 and 6 (Figs. 7b, 7d and 7f), we can conclude that it is $\mathrm{CaCO}_{3}$ which is mostly responsible for the formation of porous material.

\section{Conclusions}

Monocarboxylic derivative of epoxy resin (MCDER) has been synthesized via reaction of Epidian-6 epoxy resin and sebacic acid. The synthesized product contains free epoxy and carboxy groups. The structure of MCDER was confirmed by IR- and NMR-spectroscopy. Using derivatography it was found that MCDER is stable to $623 \mathrm{~K}$. The cross-linking of mixtures composed of Epidian5 industrial resin, TGM-3 oligoesteracrylate, MCDER and PEPA as a hardener was studied. The values of gel-fraction content and hardness were found to be dependent on the mixture composition and conditions of films formation. IR spectroscopy verified the participation of Epidian-5, MCDER, TGM-3 and PEPA in the cross-linking process. It was established that the gel-fraction content of $93.0 \%$ and film hardness of 0.90 rel.units are achieved after introduction of the synthesized MCDER (10 mass parts) and $\mathrm{CaCO}_{3}$ (10 mass parts) into the mixtures. The presence of both components affects the product morphology, increases its hardness and brittleness.

\section{References}

[1] Brostow W.: Mechanical and Thermophysical Properties of Polymer Liquid Crystals. Chapman and Hall, London 1996.

[2] Brostow W., Hagg Lobland H.E.: Materials: Introduction and Applications. John Wiley \& Sons 2017.

[3] Bratychak M., Hetmanchuk Yu.: Khimichna Technologia Syntezu Vysokomoleculiarnykh Spoluk. Vyd-vo Lviv Polytechnic, Lviv 2009. [4] Hetmanchuk Yu., Bratychak M.: Khimiya i Technologiya Polymeriv. Vyd-vo Beskid BiT, Lviv 2006.

[5] Chernin Ch., Smekhov F., Zherdeev Yu.: Epoksidnye Polymery i Kompozitsii. Khimia, Moskva 1982.

[6] Ellis B.: Chemistry and Technology of Epoxy Resins. Blackie Academic and Professional, London 1993.
[7] Bratychak Mich., Bratychak Mih., Brostow W., Shyshchak O.: Mater. Res. Innovat., 2002, 6, 24.

[8] Brzozowski Z., Szymanska E., Bratychak M.: React. Funct. Polym., 1997, 33, 217. https://doi.org/10.1016/S1381-5148(97)00045$\mathrm{X}$

[9] Iatsyshyn O., Astakhova O., Shyshchak O. et al.: Chem. Chem. Technol., 2013, 7, 73. https://doi.org/10.23939/chcht07.01.073

[10] Bashta B., Bruzdziak P., Astakhova O. et al.: Chem. Chem. Technol., 2013, 7, 413. https://doi.org/10.23939/chcht07.04.413 [11] Ivashkiv O., Namiesnik J., Astakhova O. et al.: Chem. Chem. Technol., 2015, 9, 313. https://doi.org/10.23939/chcht09.03.313 [12] Ivashkiv O., Namiesnik J., Shyshchak O. et al.: Chem. Chem. Technol., 2016, 10, 587. https://doi.org/10.23939/chcht10.04si.587 [13] Hetmanchuk Yu., Bratychak M.: Khimiya i Technologiya Oligomeriv. Vyd-vo Kyiv Univ., Kyiv 2008.

[14] Yu H., Wang L., Shi Q. et al.: Prog. Org. Coat., 2006, 55, 296. https://doi.org/10.1016/j.porgcoat.2006.01.007

[15] He H., Li K., Wang J. et al.: Mater. Design, 2011, 32, 4521. https://doi.org/10.1016/j.matdes.2011.03.026

[16] Bratychak M., Astakhova O., Shyshchak O. et al.: Chem. Chem. Technol., 2019, 13, 360. https://doi.org/10.23939/chcht13.03.360 [17] Odabiashian G., Shvets V.: Laboratornyi Praktikum po Khimii i Technologii Organicheskogo Sinteza. Khimia, Moskva 1982.

[18] Sorokin M., Lialiushko K.: Praktikum po Khimii i Technologii Plenkoobrazuyushikh Veshestv. Khimia, Moskva 1971.

[19] Bratychak M., Astakhova O., Shyshchak O. et al.: Chem. Chem. Technol., 2020, 14, 343. https://doi.org/10.23939/chcht14.03.343 [20] Odabiashian G., Shvets V.: Laboratornyi Praktikum po Khimii i Technologii Organicheskogo Sinteza. Khimia, Moskva 1982.

[21] Toroptseva A. et al.: Laboratornyi Praktikum po Khimii s Technologii Vysokomoleculiarnykh Soedineniy. Khimia, Leningrad 1972.

[22] Bratychak M., Bashta B., Bruzdziak P. et al.: Chem. Chem. Technol., 2013, 7, 41. https://doi.org/10.23939/ chcht07.01.041

Received: September 20, 2019 / Revised: October 21, 2019 / Accepted: November 15, 2019

\section{ЕПОКСИДНІ КОМПОЗИТИ З НАТУРАЛЬНИМ НАПОВНЮВАЧЕМ КАРБОНАТОМ КАЛЬЦІЮ. 3. ОДЕРЖАННЯ ЕПОКСИДНИХ КОМПОЗИТІВ У ПРИСУТНОСТІ МОНОКАРБОКСИЛЬНОЇ ПОХІДНОЇ ЕПОКСИДНОÏ СМОЛИ ЕРIDIAN-6}

Анотація. 3 використанням епоксидної смоли Eріdian-6 i себаиинової кислоти розроблена методика та синтезована монокарбоксильна похідна Epidian-6 (МКПЕС), яка містить у своїи структурі кінцеві вільні епоксидну та карбоксильну групу. Структура МКПЕС підтверджена спектральними методами дослідження. Встановлена термічна стабільність МКПЕС та вивчено формування ненаповнених та наповнених $\mathrm{CaCO}_{3}$ зиитих плівок на основі епокси-олігомерних сумішей, щзо складаються з епоксидної смоли Eріdian-5, олігоестеракрилату ТГМ3 і поліетиленполіаміну, в його присутності. 3 використанням ІЧ-спектроскопії встановлено хімізм процесу формування зиитих структур на основі епоси-олігомерних сумішей. Визначені фізико-механічні характеристики та морфологія наповнених $\mathrm{CaCO}_{3}$ зразків на основі епокси-олігомерних сумішей.

Ключові слова: епоксидна смола, себачинова кислота, олігоестеракрилат, $\mathrm{CaCO}_{3}$, затвердник, IЧ- та ЯМР-спектроскопія, структурування, фізико-механічні властивості, СЕМ. 